\title{
Efek Ondansetron Intravena terhadap Tekanan Darah dan Laju Nadi pada Anestesi Spinal untuk Seksio Sesarea
}

\author{
Annisa Isfandiary Ismandiya, ${ }^{1}$ Tinni Trihartini Maskoen, ${ }^{2}$ Ruli Herman Sitanggang ${ }^{2}$ \\ ${ }^{1}$ Instalasi Bedah Sentral Rumah Sakit Gigi dan Mulut, RSUD Lembang \\ ${ }^{2}$ Departemen Anestesiologi dan Terapi Intensif \\ Fakultas Kedokteran Universitas Padjadjaran/Rumah Sakit Dr. Hasan Sadikin Bandung
}

\begin{abstract}
Abstrak
Hipotensi merupakan komplikasi anestesi spinal yang sering ditemukan pada seksio sesarea. Pencegahan hipotensi dapat dilakukan dengan pemberian cairan, vasopresor, dan memperbaiki posisi uterus ibu saat terlentang dengan mengganjal punggung. Penelitian ini bertujuan mengetahui pengaruh ondansetron 8 mg yang diberikan 5 menit sebelum spinal anestesi dalam menjaga kestabilan hemodinamik. Penelitian ini dilakukan di Rumah Sakit Dr. Hasan Sadikin Bandung pada Januari-Maret 2014 dengan desain eksperimental secara acak klinis terkontrol tersamar ganda yang mengikutsertakan 46 ibu hamil dengan status fisik American Society of Anesthesiologist (ASA) I-II yang menjalani seksio sesarea menggunakan anestesi spinal. Setelah randomisasi secara blok permutasi, subjek penelitian dikelompokkan menjadi 2, yaitu 23 subjek kelompok kontrol mendapat $\mathrm{NaCl}$ 0,9\% dan 23 subjek kelompok perlakuan mendapat ondansetron intravena $8 \mathrm{mg}$. Tekanan darah dan laju nadi diperiksa setiap 1-15 menit setelah anestesia spinal, kemudian diperiksa tiap 3 menit sampai operasi selesai. Data hasil penelitian dianalisis dengan uji-t, Uji Mann-Whitney, dan Uji Kolmogorov-Smirnov. Analisis statistik menunjukkan perbedaan bermakna tekanan darah sistol, tekanan darah rata-rata, dan jumlah pemakaian efedrin antara kelompok kontrol dan kelompok ondansetron $(\mathrm{p}<0,05)$. Simpulan, pemberian ondansetron $8 \mathrm{mg}$ dapat mengurangi hipotensi dan menurunkan jumlah pemberian efedrin pasca-anestesi spinal pada operasi seksio sesarea.
\end{abstract}

Kata kunci: Anestesi spinal, hipotensi, ondansetron, seksio sesarea

\section{Intravenous Ondansetron Effect on Blood Pressure and Heart Rate in Caesarean Section under Spinal Anesthesia}

\begin{abstract}
Hypotension is the most common complication in spinal anesthesia during cesarean sections. One of the prevention efforts includes administering a fluid vasopressor or placing a wedge under the right hip for left uterine displacement. This study aimed to determine the effect of ondansetron $8 \mathrm{mg}, 5$ minutes before spinal anesthesia, to maintain maternal hemodynamic stability. This double-blind randomized control experimental study was conducted in Dr. Hasan Sadikin General Hospital Bandung during the period of January to March 2014 on 46 pregnant women, American Society of Anesthesiologist (ASA) II, who underwent cesarean section with spinal anesthesia. After randomization, the subjects were grouped into two groups: 23 subjects were included in the control group receiving Nacl $0.9 \%$ and 23 subjects were included in the ondansetron group receiving $8 \mathrm{mg}$ of ondansetro. Blood pressure and pulse rate were examined every minute until 15 minutes after spinal anesthesia and then every 3 minutes until the operation was complete. Data were analyzed statistically using t test, Mann Whitney Test, and Kolmogorov-Smirnov Test. The results show that there were significant differences in systol presure, average blood pressure, and use of ephedrine between the control and ondansetron group $(\mathrm{p}<0.05)$. In conclusion, the provision of $8 \mathrm{mg}$ ondansetron can prevent hypotension and reduce ephedrine use after spinal anesthesia in caesarean section.
\end{abstract}

Key words: Spinal anesthesia, caesarean section, hypotension, ondansetron, sectio sesareaspinal anesthesia

Korespondensi: Annisa Isfandiary Ismandiya, dr., SpAn, Instalasi Bedah Sentral Rumah Sakit Gigi dan Mulut, Rumah Sakit Umum Daerah Lembang, Jl. Parakan Arum No. 19, Bandung 40266, Mobile 081321676915, Email annisaisfandiary@ gmail.com 


\section{Pendahuluan}

Saat ini anestesi regional spinal adalah teknik yang sering digunakan untuk seksio sesarea. Pada tahun 2002, 95\% seksio sesarea elektif serta $87 \%$ tindakan seksio sesarea emergensi di Amerika Serikat dilakukan memakai teknik anestesia regional. ${ }^{1,2}$ Salah satu efek samping anestesia spinal yang menjadi masalah serius ialah hipotensi. Angka kejadian hipotensi dan bradikardia dilaporkan (secara retrospektif) sebesar 33\% terjadi pada pasien obstetrik, serta $13 \%$ pada pasien non obstetrik. ${ }^{2,3}$ Angka kejadian hipotensi sebagai akibat anestesia spinal pada seksio sesarea dilaporkan sebanyak $50 \%$ sampai $60 \%{ }^{3}$ Penyebab utama hipotensi adalah penurunan resistensi pembuluh darah, sedangkan bradikardia disebabkan persarafan parasimpatis yang lebih dominan, peningkatan aktivitas baroreseptor, atau rangsangan pada Bezold Jarisch reflex (BJR).,4

Intervensi yang tepat untuk mencegah atau mengatasi hipotensi akibat dari anestesi spinal adalah meningkatkan volume intravaskular dengan pemberian cairan intravena sebelum tindakan anestesia spinal atau secara mekanik dengan cara menaikkan preload dengan elevasi kaki, membungkus kaki, atau juga posisi kepala lebih rendah. Khusus untuk pasien obstetrik, trias yang rutin dilakukan adalah memberikan cairan dengan jumlah tertentu, memposisikan uterus ke kiri (left lateral displacement), dan pemberian obat vasopresor. ${ }^{5}$

Beberapa penelitian menyatakan bahwa 5-HT (serotonin) merupakan faktor penting yang berhubungan dengan induksi BJR pada keadaan penurunan volume darah sehingga efek tersebut dapat diblok dengan antagonis reseptor 5 HT-3. Hipotensi dan juga bradikardia yang terjadi akibat anestesia spinal dapat diminimalisir memakai ondansetron intravena sebagai antagonis reseptor 5HT-3 pada pasien obstetrik dengan seksio sesarea. ${ }^{6}$

Blokade simpatis dari anestesi spinal dapat menurunkan resistensi sistemik pembuluh darah dan juga mengakibatkan pengumpulan atau pooling cairan di perifer dan menyebabkan hipotensi. Mekanoreseptor di dinding jantung mencetuskan BJR yang berhubungan dengan respons sistemik pada hipervolemia ataupun hipovolemia. Respons yang akan terjadi pada hipovolemia menstimulasi respons sensoris di jantung yang terletak di ventrikel kiri serta akan merangsang BJR sehingga terjadi refleks bradikardia, vasodilatasi, dan juga hipotensi., ${ }^{3,6}$ Aktivasi pada reseptor 5HT-3 yang merupakan protein $\mathrm{G}$ yang berpasangan yaitu ligand gated fast ion channel menghasilkan peningkatan aktivitas nervus vagal eferen yang sering kali mengakibatkan bradikardia. ${ }^{3,6}$ Hal ini dapat dicegah dengan inhibisi 5HT-3 menggunakan ondansetron sebagai suatu antagonis reseptor 5HT-3. Ondansetron sebagai suatu antagonis reseptor 5HT-3 dapat mencegah serotonin memengaruhi BJR, menekan dilatasi vena, mengembalikan aliran balik vena ke jantung, serta mengurangi kejadian penurunan tekanan darah sistol serta tekanan arteri rata-rata. ${ }^{3,4,7}$ Penelitian ini bertujuan mengetahui efek pemberian ondansetron intravena prainduksi terhadap tekanan darah dan laju nadi pada seksio sesarea dengan anestesi spinal.

\section{Subjek dan Metode}

Penelitian dilakukan di Rumah Sakit Dr. Hasan Sadikin Bandung pada periode Januari-Maret 2014. Subjek penelitian adalah wanita hamil dengan seksio sesarea elektif yang memenuhi kriteria inklusi, yaitu status fisik American Society of Anesthesiologist (ASA) I-II dan tidak terdapat kontraindikasi dilakukan anestesia spinal, serta tidak termasuk kriteria eksklusi yaitu tinggi badan $<150 \mathrm{~cm}$, kehamilan risiko tinggi, polihidramnion atau oligohidramnion, gemeli, serta alergi terhadap obat-obat yang digunakan pada penelitian ini.

Penentuan besar sampel dihitung berdasar atas tujuan penelitian menguji perbedaan dua rata-rata dengan memilih tingkat kepercayaan 95\% dengan besar kekuatan uji ialah $80 \%$ dan dianggap bermakna bila nilai $\mathrm{p}<0.05$. Setiap kelompok terdapat 23 subjek yang mendapat ondansetron dan juga plasebo masing-masing. Jumlah sampel minimal dalam penelitian ini adalah 46 pasien untuk kedua kelompok. 
Tipe penelitian ini adalah eksperimental dengan cara melakukan uji klinis rancangan acak terkontrol tersamar ganda (double blind randomized controlled trial). Pengambilan sampel dilakukan secara consecutive sampling dengan alokasi subjek ke dalam salah satu kelompok memakai tabel bilangan random.

Pasien dibagi menjadi dua kelompok yaitu kelompok ondansetron dan kelompok kontrol, kemudian dilakukan pemasangan jalur vena memakai kanula vena no. 18G, alat pantau elektrokardiografi (EKG), tekanan darah noninvasif, dan pulse oksimetri.

Saat di ruang operasi, pasien berbaring terlentang dengan punggung kanan diganjal, kemudian dicatatdata-data kesadaran, tekanan darah sistol, diastol, tekanan darah rata-rata, laju nadi, laju napas, dan juga saturasi oksigen. Semua pasien mendapatkan prehidrasi cairan Ringer laktat $20 \mathrm{~mL} / \mathrm{kgBB}$ selama 15 menit. Pasien kelompok ondansetron diberikan 8 $\mathrm{mg}$ ondansetron intravena yang diencerkan menjadi $10 \mathrm{~mL}$ dan disuntikkan selama 1 menit pada 5 menit sebelum anestesia spinal. Setelah itu dilakukan pencatatan data tekanan darah sistol, diastol, tekanan darah rata-rata, laju nadi, laju napas, dan saturasi oksigen. Pada kelompok kontrol diberikan $\mathrm{NaCl}$ 0,9\% $10 \mathrm{~mL}$ selama satu menit. Anestesia spinal dilakukan pada ruang lumbal 3 sampai 4, posisi duduk, pendekatan median, dan bevel ke arah sefalad dengan jarum spinal ukuran 27G.

Anestesiatik lokal yang digunakan adalah bupivakain 0,5\% hiperbarik sebanyak 12,5 mg yang disuntikkan selama 10 detik. Pasien dibaringkan terlentang memakai satu bantal dengan punggung kanan tetap diganjal serta diberi oksigen 2-3 L/menit lewat kanul nasal. Satu menit setelah penyuntikan obat anestesia lokal, dilakukan pengukuran level analgesia memakai metode pinprick mempergunakan jarum nomor $22 \mathrm{G}$, dicatat tiap menit sampai level maksimal yang dicapai. Bila setelah 15 menit blokade sensoris negatif maka anestesia spinal dianggap gagal dan pasien dikeluarkan dari penelitian.

Pengukuran tekanan darah sistol, diastol, tekanan darah rata-rata, laju nadi, laju napas, dan saturasi oksigen dilakukan tiap 1 menit sampai 20 menit pertama, kemudian 2,5 menit sampai operasi selesai. Setelah bayi lahir, ibu diberikan drip oksitosin 20 IU dalam $500 \mathrm{~mL}$ $\mathrm{NaCl}$ 0,9\% sebanyak $10-15$ tetes per menit.

Suplemen efedrin bolus intravena $5 \mathrm{mg}$ diberikan bila pasien hipotensi (penurunan tekanan darah sistol kurang dari $90 \mathrm{mmHg}$ ), dan bila terjadi bradikardia diterapi dengan pemberian sulfas atropin $0,5 \mathrm{mg}$ intravena. Jumlah vasopresor yang diberikan pada kedua kelompok dicatat. Penelitian terhadap pasien berakhir saat efek obat anestesia spinal sudah hilang ditandai dengan anggota tubuh yang bergerak ataupun merasakan kembali sensasi nyeri.

Analisis statistika pada data hasil penelitian untuk membandingkan perbedaan pada kedua kelompok data kategori menggunakan uji chikuadrat atau juga Uji Kolmogorov-Smirnov, sedangkan untuk mengetahui perbedaan pada kedua kelompok data kuantitatif digunakan uji-t jika data berdistribusi normal, atau Uji Mann-Whitney jika data berdistribusi tidak normal. Besarnya risiko keberhasilan dihitung memakai risiko relatif dan 95\% CI (confidence interval) dan nilai kemaknaan ditentukan berdasarkan $\mathrm{p}<0,05$. Data disajikan dalam rata-rata dan dianalisis menggunakan program statistical product and service solution (SPSS) 13,0 for windows

\section{Hasil}

Hasil analisis statistika menunjukkan bahwa tidak terdapat perbedaan bermakna secara statistika pada faktor usia, tinggi badan, serta berat badan. Hasil ini menunjukkan bahwa kedua kelompok memiliki karakteristik yang seragam sebelum dilakukan perlakuan. Hasil yang sama juga ditemukan pada variabel lama operasi, tinggi blok, serta total cairan. Hal ini menunjukkan variabel pengganggu yang dapat memengaruhi hasil pada penelitian ini juga dapat disingkirkan sehingga secara statistik subjek yang diteliti adalah homogen dan layak untuk diperbandingkan (Tabel 1).

Berdasar atas hasil uji statistika tekanan darah sistol dan rata-rata terdapat perbedaan yang bermakna pada saat menit ke-2, 3, 4, 12, 
Tabel 1 Karakteristik Subjek Penelitian Kedua Kelompok Perlakuan

\begin{tabular}{|c|c|c|c|c|c|}
\hline & \multicolumn{4}{|c|}{ Kelompok } & \multirow{3}{*}{ Nilai p } \\
\hline & \multicolumn{2}{|c|}{ Kontrol $(n=23)$} & \multicolumn{2}{|c|}{ Ondansetron $(n=23)$} & \\
\hline & Rata-rata & SB & Rata-rata & SB & \\
\hline Usia (tahun) & 29,87 & 5,50 & 31,13 & 5,20 & $0,429 *$ \\
\hline Tinggi badan $(\mathrm{cm})$ & 158,74 & 4,33 & 160,61 & 3,96 & $0,134^{*}$ \\
\hline Berat badan (kg) & 68,74 & 4,66 & 68,17 & 4,80 & $0,782^{* *}$ \\
\hline Lama operasi (menit) & 60,00 & 7,98 & 62,26 & 15,14 & $0,831^{* *}$ \\
\hline Perdarahan (mL) & 689,13 & 79,71 & 765,22 & 95,86 & $0,011^{* *}$ \\
\hline \multicolumn{6}{|l|}{ Tinggi blok } \\
\hline $\mathrm{T} 4$ & 1 & & 0 & & $0,314^{* *}$ \\
\hline T5 & 6 & & 6 & & \\
\hline T6 & 16 & & 14 & & \\
\hline $\mathrm{T} 8$ & 0 & & 3 & & \\
\hline Cairan (mL) & 1686,96 & 198,41 & 1652,17 & 164,79 & $0,761^{* *}$ \\
\hline Lama puasa (jam) & 6,13 & 0,55 & 5,65 & 0,57 & $0,008^{* *}$ \\
\hline
\end{tabular}

Keterangan: nilai $\mathrm{p}^{*}$ ) dihitung berdasarkan uji-t dan nilai $\mathrm{p}$

**) dihitung berdasarkan Uji Mann-Whitney, nilai p bermakna $(\mathrm{p}<0,05)$

13, dan menit ke-18 antara kelompok kontrol dan kelompok ondansetron yang menyatakan bahwa ondansetron memiliki nilai sistol lebih tinggi daripada kelompok kontrol, hal ini sama pada hasil tekanan darah rata-rata (Gambar 1, Gambar 3). Berdasarkan hasil uji statistika pada tekanan darah diastol dan laju nadi tidak terdapat perbedaan yang bermakna (Gambar 2, Gambar 4).

Hasil penelitian ini didapatkan perbedaan bermakna secara signifikan $(p=0,005)$ antara kelompok kontrol dan kelompok ondansetron pada pemakaian obat vasopresor efedrin. Pada kelompok ondansetron penggunaan efedrin lebih sedikit jumlahnya bila dibanding dengan kelompok kontrol, penggunaan efedrin ratarata pada kelompok kontrol maksimal $30 \mathrm{mg}$ dan minimal $10 \mathrm{mg}$, sedangkan pada kelompok ondansetron maksimal $10 \mathrm{mg}$ dan minimal $0 \mathrm{mg}$. Penggunaan efedrin lebih banyak pada kelompok kontrol dibanding dengan kelompok ondansetron.

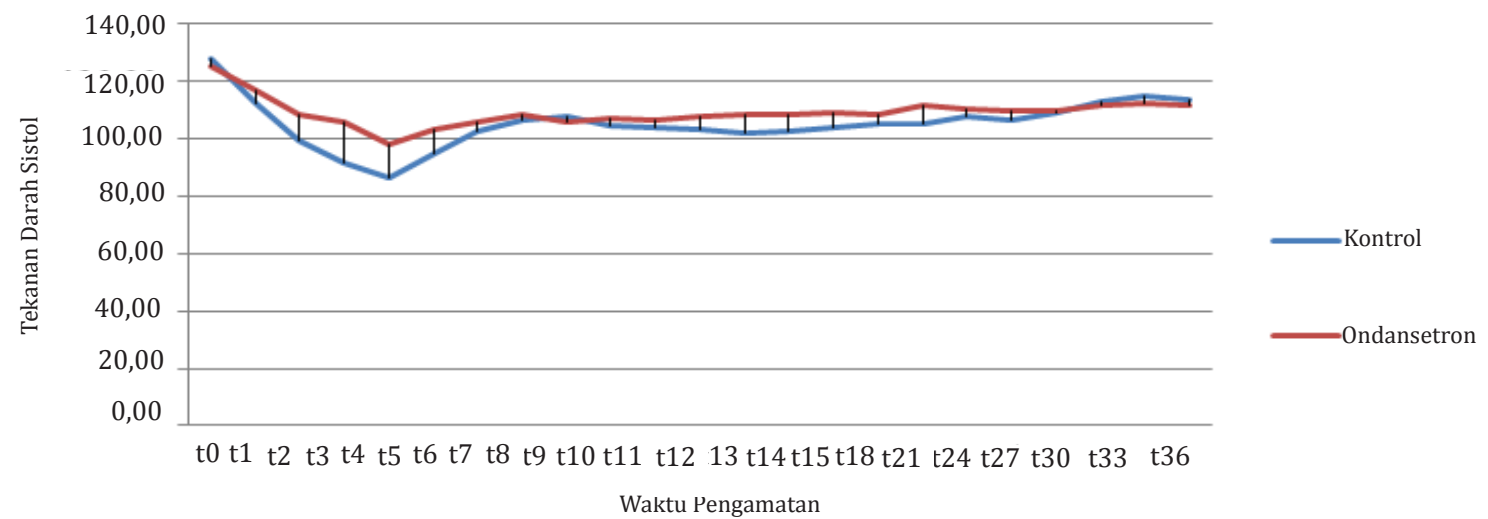

Gambar 1 Perbandingan Tekanan Darah Sistol antara Kelompok Kontrol dan Kelompok Ondansetron 


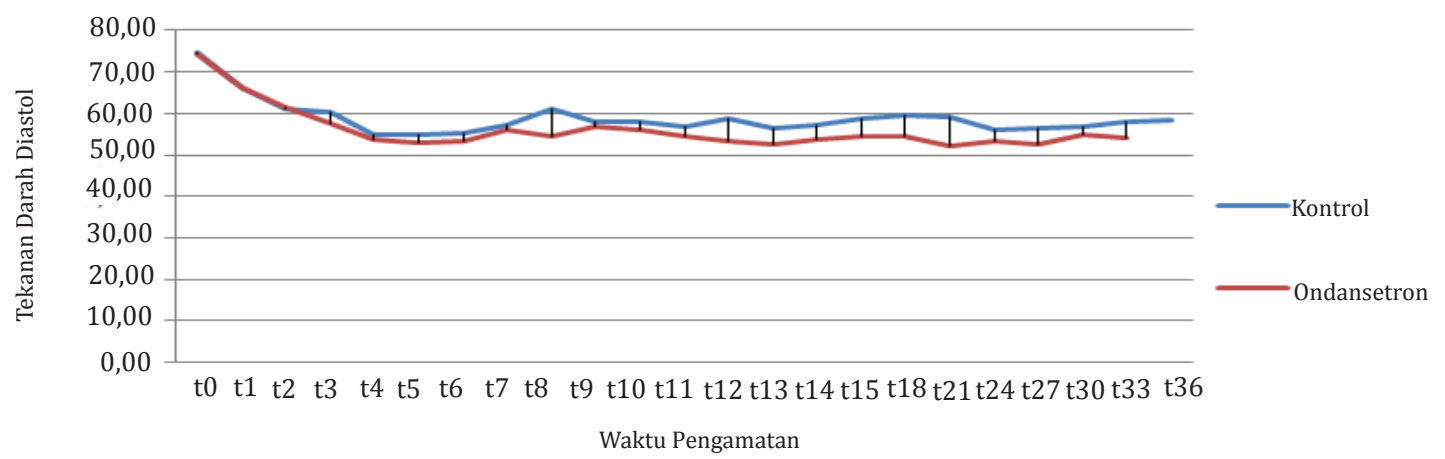

Gambar 2 Perbedaan Tekanan Darah Diastol antara Kelompok Kontrol dan Kelompok Ondansetron

\section{Pembahasan}

Data karakteristik usia penderita (Tabel 1) di antara kedua kelompok perlakuan, yaitu kelompok kontrol dan kelompok ondansetron ternyata tidak menunjukkan perbedaan yang bermakna dalam hal usia, tinggi badan, berat badan, lama operasi, tinggi blok, dan cairan. Hal tersebut menunjukkan bahwa sampel yang diambil dalam penelitian ini relatif homogen secara statistika $(p>0,05)$ sehingga kedua kelompok layak diperbandingkan. Pemberian cairan pada kelompok kontrol secara rata-rata lebih banyak tetapi tidak bermakna secara statistika. Faktor-faktor yang memengaruhi derajat dan insidens hipotensi pada anestesia spinal adalah jenis obat anestesia lokal, tingkat penghambatan sensorik, usia, jenis kelamin, berat badan, kondisi fisik, posisi pasien, dan manipulasi operasi. ${ }^{8}$

Faktor lain yang memengaruhi ketinggian blokade juga diseragamkan seperti barisitas, volume, dosis obat anestesia lokal, dan juga posisi penyuntikan. Selain itu, usia juga dapat memengaruhi derajat hipotensi. Setelah usia 50 tahun, insidens hipotensi meningkat secara progresif dari $10 \%$ pada usia 50 tahun menjadi $30 \%$ pada usia 80 tahun. Pada usia muda sehat biasanya memperlihatkan penurunan tekanan darah yang kurang berat dibanding dengan penderita tua dengan tinggi anestesia spinal yang sama. ${ }^{9}$ Pada penelitian ini selain usia yang dihomogenkan dengan kriteria inklusi ibu hamil, juga dilakukan pengujian secara statistika.

Keadaan fisik subjek penelitian yang juga akan memengaruhi hasil penelitian seperti berat badan dan tinggi badan, juga dilakukan

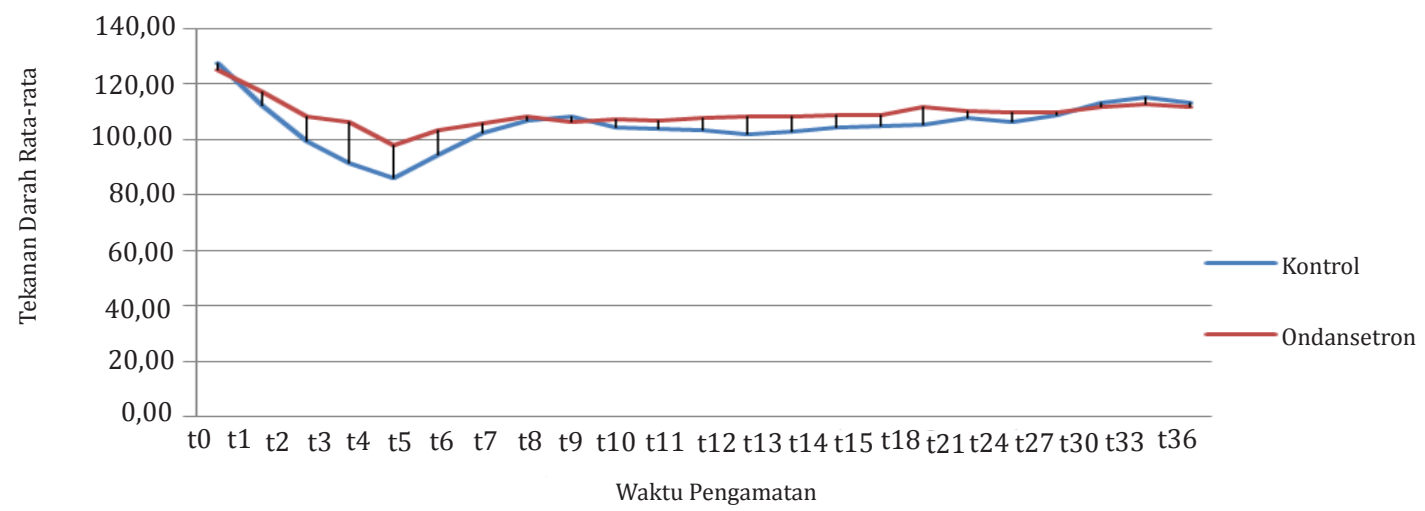

Gambar 3 Perbedaan Tekanan Darah Rata-Rata antara Kelompok Kontrol dan Kelompok Ondansetron 


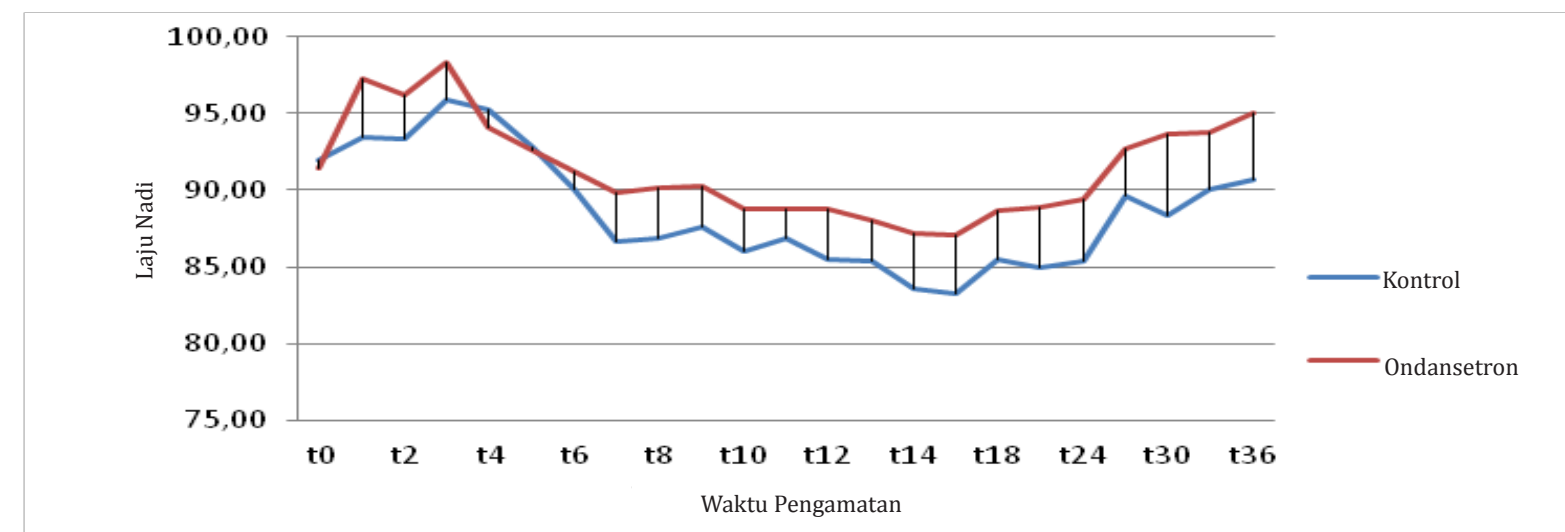

Gambar 4 Perbedaan Laju Nadi antara Kelompok Kontrol dan Kelompok Ondansetron

pengujian secara statistika. Hal ini dapat dilihat dari Tabel 1 yang menunjukkan karakteristik usia, berat badan, serta tinggi badan sebelum tindakan anestesia tidak bermakna secara statistika $(\mathrm{p}>0,05)$.

Ketinggian blokadejuga akan memengaruhi derajat dan insidens hipotensi. Pada ketinggian blok setinggi vetebra servikal tingkat hipotensi lebih berat dan lebih banyak dibanding dengan ketinggian anestesia spinal setinggi vetebra torakal. Menurut penelitian di Inggris, 30\% pasien yang mendapat anestesia spinal tinggi (T4-T6) mengalami penurunan tekanan darah sebesar 40\%. Batas kritis dari blok simpatis adalah umbilikus, bila blok lebih tinggi maka akan terjadi penurunan tekanan darah yang lebih progresif dari refleks kompensasi. Pada anestesia spinal yang rendah, tekanan rata-rata arteri brakialis turun sekitar 21\%, sedangkan pada anestesia spinal tinggi turun sebesar $44 \% .^{10}$ Ketinggian blok yang ditolerir pada penelitian ini hanya sampai ketinggian blok torakal 4-8. Ketinggian blok di atas torakal 4 dan di bawah torakal 8 akan dikeluarkan dari penelitian karena blok di bawah torakal delapan biasanya ibu masih merasakan nyeri saat manipulasi operasi. Ketinggian >torakal 4 berpotensi menimbulkan bradikardia. Selain itu, pada penelitian ini ketinggian blok juga diuji secara statistika.

Usaha untuk menghomogenisasikan faktor yang dapat memengaruhi tekanan darah dan laju nadi akibat tindakan anestesia spinal dan juga tindakan operasi pada penelitian ini juga diperhitungkan. Hasilnya didapatkan bahwa ketinggian blokade, lama operasi, dan jumlah cairan pada kedua kelompok dianggap homogen secara statistik $(p>0,05)$. Walaupun pemberian cairan rata-rata pada kelompok kontrol lebih banyak, tetapi tidak bermakna secara statistika. Pemeriksaan tekanan darah dan juga laju nadi sebelum dilakukan anestesia spinal menunjukkan tidak berbeda bermakna secara statistika. Kedua kelompok memiliki karakteristik hemodinamik yang sama.

Berdasar atas hasil uji statistika pada tekanan darah sistol terdapat perbedaan yang bermakna pada saat menit ke-2, 3, 4, 12, 13, dan menit ke-18 antara kelompok kontrol dan kelompok ondansetron yang menyatakan bahwa ondansetron memiliki nilai sistol lebih tinggi daripada kelompok kontrol.

Hasil menunjukkan bahwa penggunaan ondansetron sebelum anestesia spinal dapat mengurangi penurunan sistol dan juga ratarata dibanding dengan kelompok yang tidak menggunakan ondansetron. Hal ini sesuai dengan teori bahwa ondansetron sebagai antagonis reseptor 5HT-3 dapat menghambat BJR serta mengurangi penurunan tekanan darah sistol dan rata-rata. Berdasarkan hasil uji statistika pada tekanan darah diastol dan juga laju nadi tidak terdapat perbedaan yang bermakna, pada tekanan darah diastol yang tidak bermakna menandakan bahwa kecukupan cairan pasien sudah terpenuhi. Hal ini sesuai dengan penelitian pada tahun 2008 bahwa dari 71 sampel yang terbagi dua grup 
antara grup yang mendapat ondansetron 8 mg dan plasebo, didapatkan bahwa pada grup ondansetron mengalami penurunan tekanan darah sistol dan tekanan arteri rata-rata lebih minimal dibanding dengan plasebo, tetapi ondansetron kurang berpengaruh terhadap tekanan darah diastol dan juga penurunan laju nadi. $^{5}$

Metode yang digunakan sesuai serta sama dengan penelitian sebelumnya, dengan jumlah sampel yang telah dihitung serta dilakukan penarikan statistika yang benar, keadaan ini berlangsung selama tiga bulan berdasar atas banyaknya sampel sehingga sampel tercukupi, kepustakaan sudah lengkap, dan juga sesuai dengan penelitian ini. Tidak ada keterbatasan penelitian dalam keadaan ini. Penyebab utama hipotensi terjadi karena penurunan resistensi vaskular, sedangkan bradikardia terjadi karena lebih dominannya persarafan parasimpatis, peningkatan aktivitas baroreseptor, atau juga rangsangan pada Bezold Jarisch reflex (BJR). ${ }^{3}$

Blokade simpatis pada anestesia spinal menurunkan resistensi sistemik pembuluh darah dan juga mengakibatkan pengumpulan cairan atau pooling cairan pada perifer, serta mengakibatkan hipotensi. Mekanoreseptor pada dinding jantung mencetuskan BJR yang berhubungan dengan respons sistemik pada hipervolemia atau hipovolemia. Respons yang terjadi pada hipovolemia akan menstimulasi respons sensoris pada jantung yang terletak di ventrikel kiri dan merangsang BJR sehingga terjadi refleks bradikardia, vasodilatasi, serta hipotensi. ${ }^{3}$ Aktivasi dari 5HT-3 reseptor yang merupakan protein $\mathrm{G}$ yang berpasangan, yaitu ligand gated fast ion channel, menghasilkan peningkatan aktivitas dari nervus vagal eferen yang sering menyebabkan bradikardia. ${ }^{3,5}$

Bradikardia sebagian disebabkan tonus parasimpatis yang berlebihan akibat blokade serabut simpatis cardiac accelerator $\mathrm{T}_{1}-\mathrm{T}_{5}$ akan tetapi, sebab utamanya adalah penurunan preload. Penurunan preload akan mengaktifkan kelompok refleks yang bertanggung jawab terhadap regangan volume intrakardial dan atau reseptor pacemaker. Penurunan volume ventrikel secara tiba-tiba akan menyebabkan bradikardia berat dan asistol melalui aktivasi paradoksal BJR. ${ }^{6}$

Efedrin akan diberikan jika tekanan darah arteri rata-rata kurang dari 20\% tekanan arteri rata-rata praspinal anestesia atau pada tekanan sistol $<90 \mathrm{mmHg}$. Hasil penelitian ini menunjukkan kebutuhan pemberian efedrin yang berbeda secara bermakna antara dua kelompok. Penggunaan efedrin lebih banyak pada kelompok kontrol bila dibanding dengan kelompok ondansetron. Hasill tersebut sesuai dengan penelitian tahun 2012 bahwa dari 52 sampel yang terbagi dalam 2 grup antara grup mendapat ondansetron $4 \mathrm{mg}$ dan plasebo pada seksio sesarea yang dilakukan anestesia spinal, didapatkan bahwa pada grup ondansetron kejadian hipotensi lebih minimal dibanding dengan plasebo dan penggunaan vasopresor lebih sedikit. ${ }^{3}$

\section{Simpulan}

Berdasar atas hasil penelitian ini didapatkan simpulan bahwa pemberian ondansetron 8 mg mengurangi penurunan tekanan darah sistol dan juga tekanan darah rata-rata, namun pada tekanan darah diastol dan juga laju nadi tidak bermakna. Penggunaan efedrin pada kelompok ondansetron lebih sedikit. Hal ini menunjukkan bahwa derajat hipotensi yang dicegah oleh pemberian ondansetron secara statistika sedikit lebih baik dibanding dengan kelompok kontrol.

\section{Daftar Pustaka}

1. Velde MVD. Spinal anesthesia in obstetric patient: prevention and treatment of hypotension. Acta Anaesth Belg. 2006;57:383-6.

2. Morgan G, Mikhail MS, Murray MJ. Clinical anesthesiology. Edisi ke-4. New York: McGraw Hill Company; 2006.

3. Sahoo T, Sendasgupta C, Goswami A, Hazra A. Reduction in spinal-induced hypotension with ondansetron in parturients undergoing caesarean section: a double-blind randomised, plasebocontrolled study. Int J Obstet Anesthesia. 2012;2(1):24-8. 
4. Denryter M, Lim P, Ponik J. Ondansetron given intravenously to attenuate hypotension and bradicardia during spinal anesthesia in cesarean delivery. Literature Review Oakland University. 2012:212-30.

5. Siddik S, Nasr VG, Taha SK, Zbeide RA, ShehadeJMA.Arandomized trialcomparing colloid preload to colload during spinal anesthesia for elective cesarean delivery. Anesth Analg. 2009;109:1219-24.

6. Owczuk R, Wenski W, Polak-Krzeminska A. Ondansetron given intravenously attenuates arterial blood pressure drop due to spinal anesthesia: a double-blind, plasebo-controlled study. Reg Anesth Pain Med. 2008;33:332-9.

7. Ye JH, Ponnudurai R, Schaefer R.
Ondansetron: a selective $5-\mathrm{HT}_{3}$ receptor antagonist and its applications in CNS-related disorders. CNS Drug Rev. 2001;7:199-213.

8. Green N, Brull SJ. Physiology of spinal anesthesia. Edisi ke-4. Baltimore: William Wilkins; 1993.

9. Brown D. Spinal, epidural and caudal anesthesia. Dalam: Miller R., penyunting. Millers anesthesia. Edisi ke-7. Philadelphia: Churchill Livingstone; 2009. hlm. 1653-84.

10. Bernard C. Complication of regional anesthesia. Dalam: Mulroy M, Bernard CM, Mc Donald SB, Salinas FV, penyunting. A practical approach to regional anesthesia. Edisi ke-4. Baltimore: Lippincott Williams \& Wilkins; 2009. hlm. 24-38. 